\title{
Pengaruh Modal Kerja Terhadap Net Profit Margin pada Industri Makanan dan Minuman yang Terdaftar di BEI
}

\section{The effect of working capital on net profit margin in food and beverage companies listed on IDX}

\author{
Karunia Putri Augustina Dwi Anggiyani \\ Program Studi D3 Keuangan dan Perbankan, Politeknik Negeri Bandung \\ E-mail: karuniaputriada31@gmail.com
}

\section{Leni Nur Pratiwi}

Jurusan Akuntansi, Politeknik Negeri Bandung

E-mail: leni.pratiwi@polban.ac.id

\section{Banter Laksana}

Jurusan Akuntansi, Politeknik Negeri Bandung

E-mail: banter.laksana@polban.ac.id

\begin{abstract}
The aims of this research are to analyze the effect of Working Capital Turnover, Inventory Turnover, Cash Turnover, Receivables Turnover, and Short-term Debt to Net Profit Margin (NPM) at food and beverage industry listed on BEI (Indonesia Stock. Exchange) Period 2017-2019. This research is using purposive sampling method and obtained a sample of 6 companies. The analysis used to determine the effect of Working Capital Turnover, Inventory Turnover, Cash Turnover, Receivable Turnover, and Short-Term Debt on Net Profit Margin (NPM) is a statistical analysis with using the help of SPSS 22.0 software. The results of this study indicate that the Working Capital Turnover, Inventory Turnover, Cash Turnover, Receivable Turnover and Short Term Debt variables simultaneously have a significant effect on Net Profit Margin (NPM). Working Capital Turnover, Inventory Turnover and Short-term Debt partially have a negative effect on NPM. Receivables turnover has a positive effect on NPM. whereas, cash turnover does cash turnover does not have an effect on NPM.
\end{abstract}

Keywords: working capital turnover, inventory turnover, cash turnover, receivable turnover, shortterm debt, net profit margin

\section{Pendahuluan}

Dalam dunia bisnis akan terjadi persaingan yang ketat antar perusahaan. perusahaan harus meningkatkan efisiensi dan efektifitas untuk menjaga kelangsungan perusahaan. Salah satunya dengan meningkatkan profitabilitas melalui peningkatan kuantitas atau target penjualan. Strategi peningkatan kuantitas produk tentunya akan mempengaruhi berbagai aspek di dalam perusahaan terutama modal kerja. Menurut Kasmir (2014:250) dalam Susanti, Rahayu dan Topowijono (2014) kegiatan operasional perusahaan didanai melalui modal kerja. Komponen modal kerja terdiri dari kas, persediaan, piutang, bank, surat berharga dan aktiva lancar lainnya. Dalam perusahaan manufaktur modal kerja sangat penting, karena perusahaan manufaktur membutuhkan dana yang tinggi untuk melakukan kegiatan operasionalnya. Sehingga, perusahaan harus mengelola modal kerjanya dengan cermat supaya dapat menghasilkan keuntungan yang besar dengan biaya yang rendah. Semakin besar dana pada modal kerja akan menyebabkan penurunan profitabilitas karena 
dana yang menganggur atau dana diam lebih besar, selain itu juga perusahaan dianggap tidak produktif. Sebaliknya, jika dana dalam di modal kerja terlalu kecil akan meningkatkan resiko terganggunya kegiatan perusahaan (Yani dan Martha, 2019). Jadi, pengelolaan modal kerja sangatlah penting bagi perusahaan manufaktur yang sangat bergantung pada item-item pada modal kerja seperti persediaan, kas, piutang dan utang jangka pendek.

Profitabilitas merupakan kemampuan perusahaan dalam menghasilkan laba (Farahanny dan Saifi, 2019). Untuk menilai kemampuan dalam menghasilkan keuntungan perusahaan dapat menggunakan rasio NPM. Net profit margin dipakai sebagai alat ukur bagi investor untuk memprediksi profitabilitas dalam perusahaan di tahun berikutnya dengan menggunakan peramalan penjualan yang dibuat oleh manajemen perusahaan. Semakin tinggi NPM dalam perusahaan, para penanam modal akan terdorong untuk melangsungkan investasi pada perusahaan (Setiawan dan Sari, 2018). Hal itu karena besarnya NPM dalam perusahaan menggambarkan bahwa perusahaan semakin produktif (Wulandari, Oemar dan Hartono).

Sepanjang tahun 2018 industri manufaktur berkontribusi sebesar 19,86\% terhadap struktur PDB nasional. Berdasarkan laporan Making Indonesia 4.0 pada tahun 2018, Kementrian Perindustrian akan mengembangkan lima sektor manufaktur. Lima industri tersebut adalah industri tekstil, otomotif, makanan dan minuman, elektronik dan kimia. Perusahaan makanan dan minuman menjadi merupakan sektor manufaktur unggulan dalam implementasi industri 4.0. Hal in disebabkan karena industri tersebut memiliki kontribusi yang besar terhadap perekonomian. Kinerja industri makanan dan minuman tercatat terus positif, hal ini terlihat pada tahuni2018 perusahaan makanan dan minuman tumbuh sebesar 7,91\%, angka perkembangan tersebut melebihi angka perkembangan ekonomi nasional sebesar 5,17\%. Produksi pada industri makanan dan minuman juga meningkat di tahun 2018 sebesar 23,44\%. Hal tersebut menjadi salah satu penyebab meningkatnya produksi industri manufaktur sebesar 3,90\% (www.kemenperin.go.id).

Tabel 1. Perbandingan Modal Kerja dan NPM di Industri Makanan dan Minuman

\begin{tabular}{|c|c|c|}
\hline Tahun & Modal Kerja & NPM \\
\hline 2016 & $\mathrm{Rp} \quad 4.062 .877$ & 8,21 \\
\hline 2017 & $\mathrm{Rp} \quad 4.571 .792$ & 11,02 \\
\hline 2018 & $\mathrm{Rp} \quad 2.925 .921$ & 11,61 \\
\hline 2019 & $\mathrm{Rp} \quad 4.461 .051$ & 12,89 \\
\hline
\end{tabular}

Sumber : Data Olahan dari Laporan Keuangan Industri Makanan \& Minuman

Berdasarkan tabel 1, modal kerja di industri makanan dan minuman setiap tahun nya mengalami kondisi yang fluktuasi. Sedangkan NPM pada industri makanan dan minuman terus meningkat meskipun modal kerjanya mengalami penurunan. Pada tahun 2018 modal kerja di industri makanan dan minuman turun sebesar 36\% dari Rp4.571.792 menjadi Rp2.925.921. Penurunan tersebut disebabkan karena hutang lancar dalam perusahaan pada tahun 2018 meningkat cukup drastis, sedangkan aktiva lancar perusahaan menurun. Kemudian meningkat kembali pada tahun 2019, hal tersebut terjadi akibat turunnya hutang kalokemarenlancar dan meningkatnya aktiva lancar dalam perusahaan. Namun, meskipun modal kerja perusahaan mengalami penurunan, NPM pada industri makanan dan minuman terus mengalami kenaikan dari $11,02 \%$ menjadi $11,61 \%$. Kenaikan NPM tersebut menandakan bahwa kegiatan operasional dalam perusahaan semakin efisien. Perusahaan mengurangi biaya - biaya yang tidak dibutuhkan sehingga dapat mengoptimalkan laba bersih. 
Berdasarkan data diatas, pertumbuhan modal kerja pada perusahaan makanan dan minuman tidak selalu diikuti dengan pertumbuhan NPM. Hal ini tidak sesuai dengan teori Harjito dan Martono (dalam Marda, 2019:13) yang menyatakan semakin tinggi profitabilitas dalam perusahaan disebabkan karena modal kerja di dalam perusahaan juga semakin tinggi. Modal kerja perusahaan digunakan untuk membiayai kegiatan operasional. Sehingga, tingginya modal kerja diharapkan dapat meningkatkan penjualan dalam perusahaan. Dengan meningkatnya penjualan, perusahaan akan memperoleh keuntungan yang besar.

\section{Rumusan Masalah}

1. Apakah secara individu NPM dipengaruhi oleh perputaran komponen modal kerja dengan pengaruh yang positif?

2. Apakah secara simultan NPM dipengaruhi oleh perputaran komponen modal kerja dengan pengaruh yang positif?

\section{Tujuan Penelitian}

1. Untuk mengetahui adakah pengaruh positif dari perputaran komponen modal kerja secara individu terhadap NPM pada industri makanan dan minuman yang terdaftar di BEI periode $2017-2019$.

2. Untuk mengetahui adakah pengaruh positif dari perputaran komponen modal kerja secara simultan terhadap NPM pada industri makanan dan minuman yang terdaftar di BEI periode 2017 - 2019.

\section{Kajian Pustaka}

\section{Perputaran Modal Kerja}

Menurut Munawir (2014:80) untuk menilai dan mengukur keefektifan modal kerja dalam perusahaan dapat diukur dengan menggunakan rasio perputaran modal kerja. Rasio ini menunjukan berapa kali dana dalam modal kerja berputar dalam satu periode. Semakin cepat perputaran modal kerja, maka periode perputaran modal kerja semakin pendek. Hal tersebut menggambar kan perusahaan semakin efisien karna dapat mengelola modal kerjanya dengan baik (Muslimah dan Syarief, 2020). Hal tersebut dapat meningkatkan profitabilitas dalam perusahaan. Perputaran modal kerja dapat dihitung dengan rumus :

$$
\text { Perputaran Modal Kerja }=\frac{\text { Pendapatan }}{\text { Rata }- \text { rata } \text { modal kerja }}
$$

\section{Perputaran Persediaan}

Menurut Baridwan (2014:149) barang yang dibeli untuk dijual kembali atau digunakan untuk memproduksi barang-barang yang akan dijual pada masa yang akan datang adalah persediaan. Untuk menghitung berapa kali dana yang tertanam pada persediaan berputar dalam satu periode dapat menggunakan rasio perputaran persediaan. Perputaran persediaan digunakan untuk melihat sejauh mana kemampuan perusahaan atau seberapa efisien perusahaan dalam mengelola persediaannya. Dalam perusahaan, jumlah persediaan disarankan untuk tidak terlalu banyak dan juga tidak terlalu sedikit. Persediaan yang terlalu banyak dalam perusahaan akan menimbulkan resiko barang rusak atau barang kadaluwarsa karena terlalu lama tersimpan digudang. Namun, jika perputaran persediaan terlalu kecil akan menghambar kegiatan operasional dalam memproduksi barang karena kekurangan bahan baku. Perputaran persediaan dapat di hitung dengan rumus :

$$
\text { Perputaran Persediaan }=\frac{\text { Harga Pokok Penjualan }}{\text { Rata }- \text { rata persediaan }}
$$




\section{Perputaran Kas}

Perputaran kas merupakan perbandingan penjualan dengan jumlah rata-rata kas. Rasio ini dipakai untuk menilai berapa kali dana dalam kas berputar dalam satu periode. Kas yang besar dalam perusahaan menunjukan bahwa perusahaan selalu siap jika membutuhkan dana untuk keperluan yang penting. Tingginya perputaran kas menunjukan tingginya volume penjualan yang dilakukan perusahaan. Namun rasio perputaran kas yang rendah mengindikasi kas yang dimiliki perusahaan tidak dikelola dengan efisien, karena hal tersebut menggambarkan adanya dana yang menganggur dan tidak diputar. Rasio perputaran kas dapat dihitung dengan rumus :

$$
\text { Perputaran Kas }=\frac{\text { Penjualan }}{\text { Rata }- \text { rata kas }}
$$

\section{Perputaran Piutang}

Munawir (2014:123) menyatakan bahwa piutang merupakan hak atas penjualan barang ataupun jasa yang dilakukan secara kredit terhadap pihak lain. Untuk mengukur tingkat efisiensi piutang dalam perusahaan dapat menggunakan rasio perputaran piutang. Menurut Niswonger (1999:337) dalam Anita (2017) perputaran piutang merupakan rasio yang dipakai untuk menghitng berapa kali dan seberapa sering piutang dalam perusahaan berputar dan kembali menjadi kas dalam satu periode. Tingginya perputaran piutang dalam perusahaan menggambarkan piutang yang dimiliki perusahaan tertagih. Jika perputaran piutang rendah, akan menimbulkan resiko tidak tertagihnya piutang yang akan menyebabkan kerugian. Perputaran piutang dapat dihitung dengan rumus :

$$
\text { Perputaran Piutang }=\frac{\text { Penjualan }}{\text { Rata }- \text { rata piutang }}
$$

\section{Hutang Jangka Pendek}

Menurut Munawir (2014:14) hutang jangka pendek adalah hutang yng harus dilunasi perusahaan satu tahun sejak tanggal neraca. Terdapat beberapa jenis hutang jangka pendek, yaitu hutang dagang, hutang wesel, hutang jangka panjang yang jatuh tempo pada periode ini, hutang dividen, uang muka dan jaminan yang dapat diminta kembali, dana yang dikumpulkan orang ketiga, hutang biaya, hutang bonus, hutang gaji dan upah, dan pendapatan yang diterima dimuka. Menurut Baridwan (2014:216) hutang jangka pendek dikatakan sudah pasti bila memenuhi 2 syarat yaitu :

a. Sudah terjadi transaksi sehingga kewajiban untuk membayar sudah pasti,

b. Jumlah yang harus dibayar pasti

\section{Net Profit Margin}

Menurut Kasmir (2012 : 197) dalam Tarsiah (2017) NPM adalah rasio yang dipakai untuk menghitung jumlah keuntungan atas penjualan. Net profit margin menggambarkan berapa keuntungan yang didapat perusahaan dari penjualan. Semakin tinggi NPM dalam perusahaan akan membuat para penanam modal tertarik untuk menanamkan modalnya pada perusahaan. Net profit margin yang tinggi menunjukan tingkat harga barang yang di tetapkan perusahaan tepat dan biaya produksi yg dikeluarkan perusahaan dikendalikan dengan baik. Net profit margin dapat dihitung dengan rumus :

$$
\text { Net Profit Margin }=\frac{\text { Laba Bersih Setelah Pajak }}{\text { Penjualan }}
$$

\section{Kerangka Pemikiran}

Perusahaan makanan dan minuman memiliki tiga kegiatan, yaitu kegiatan operasional, investasi dan pendanaan. Kegiatan operasional perusahaan dibiayai melalui modal kerja. Modal kerja dalam perusahaan dibentuk oleh beberapa komponen meliputi kas, piutang dan persediaan (Sofyan dan 
Saifi, 2019). Hubungan antara perputaran komponen modal kerja dengan NPM dapat diketahui dengan cara melihat apakah pada saat perputaran komponen modal kerja naik maka NPM perusahaan juga akan naik. Modal kerja yang memadai akan mengakibatkan perusahaan semakin produktif dan profitabilitas meningkat. Sehingga dapat disimpulkan bahwa untuk meningkatkan NPM, perusahaan harus mengelola komponen modal kerjanya dengan baik dan efisien.

Skema Kerangka Pemikiran:

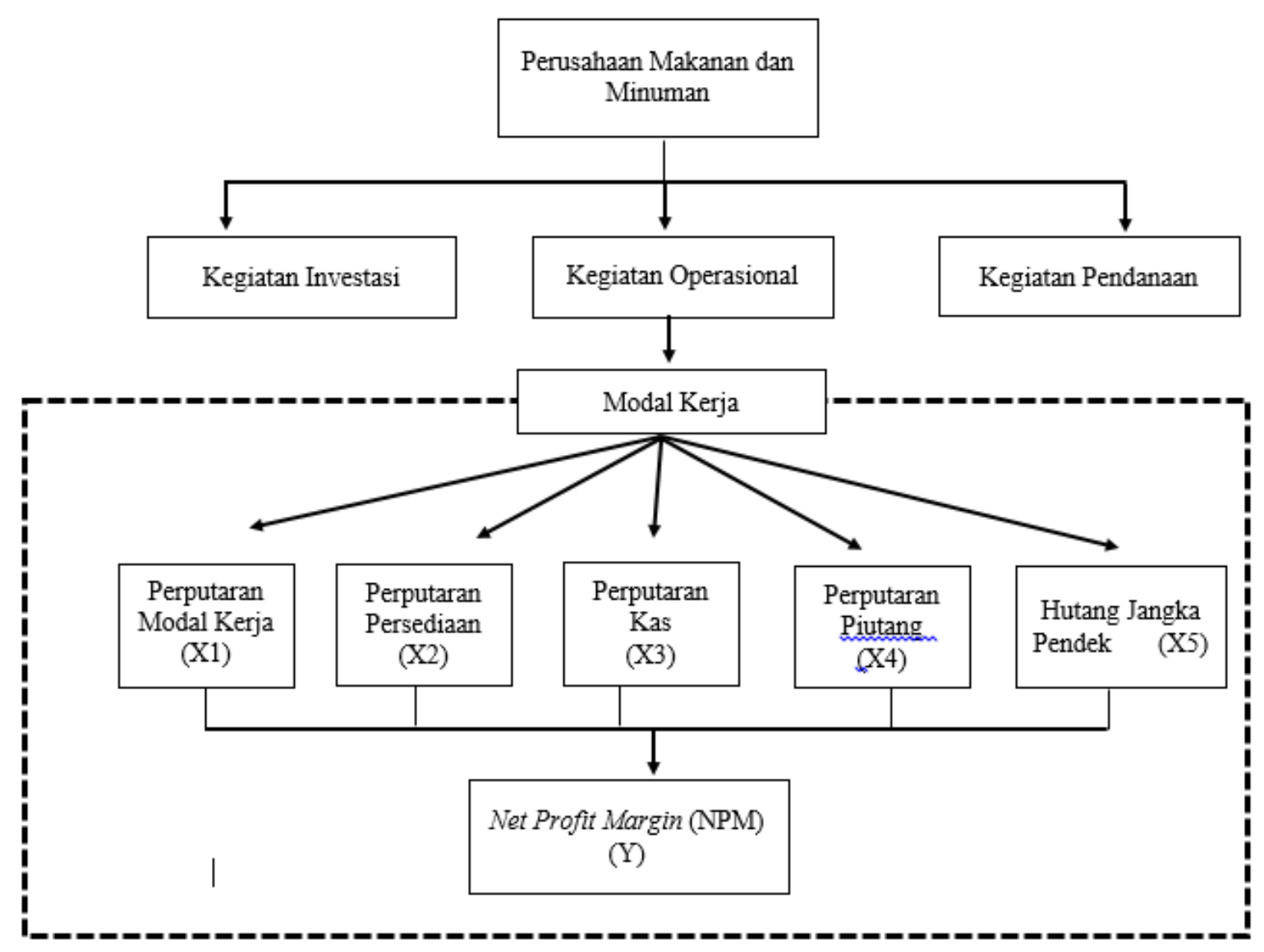

Gambar 1. Kerangka Pemikiran

\section{Hipotesis Penelitian}

H1 : NPM dipengaruhi positif dan signifikan oleh variabel perputaran modal kerja secara individu H2 : NPM dipengaruhi positif dan signifikan oleh variabel perputaran persediaan secara individu H3 : NPM dipengaruhi positif dan signifikan oleh variabel perputaran kas secara individu H4 : NPM dipengaruhi positif dan signifikan oleh variabel perputaran piutang secara individu H5 : NPM dipengaruhi positif dan signifikan oleh variabel hutang jangka pendek secara individu H6 : NPM secara simultan dipengaruhi positif dan signifikan oleh variabel perputarn modal kerja, perputaran persediaan, perputaran kas, perputarn piutang dan hutang jangka pendek

\section{Metode Penelitian}

Metode yng dipakai oleh peneliti yaitu metode kuantitatif, dimana data disajikan dalam bentuk angka yang di peroleh dari laporan keuangan. Penelitian ini bersifat asosiatif yang tujuannya untuk melihat adanya hubngan atau pengaruh antra dua variabel atau lebih (Sugiyono, 2017:69). 


\section{Populasi}

Populasi yang dipakai oleh peneliti yaitu perusahan manufaktur sektor makanan dan minumn di BEI dengn jumlah 26 perusahaan.

\section{Sampel}

Sampel yang dipakai oleh peneliti sebanyak 6 perusahaan. Perusahaan yang ditetapkan menjadi sampel dipilih dengan teknik purposive sampling dengan dua kriteria yang sudah di tetapkan oleh peneliti. Kriteria yang dimaksud dalam penelitian ini adalah sebagai berikut:

1. Perusahaan yang digunakan sebagai sampel adalah perusahaan manufaktur sektor industri makanan dan minuman yang masih terdaftar di BEI selama tahun 2017 - 2019.

2. Data yang diperlukan tersedia dan dapat dianalisis.

\section{Jenis dan Sumber Data}

Penelitian ini memakai data kuantitatif. Data tersebut didapat dari sumber data sekunder berupa laporan keuangan triwulan dari perusahaan yang ditetapkan sebagai sampel penelitian. Data sekunder diperoleh dengan cara mendownload laporan keuangan tersebut dari website perusahaan dan website idx.

\section{Teknik Pengumpulan Data}

Peneliti mengumpulkan data dari dokumentasi berupa laporan keuangan triwulan tiap tahun pada perusahaan yang menjadi objek penelitian. Selain itu, peneliti juga melakukan studi pustaka untuk mempelajari jurnal serta buku yang memiliki kaitan dengan masalah yang diteliti.

\section{Variabel Operasional}

\begin{tabular}{|c|c|c|c|c|}
\hline No & Jenis Variabel & Definisi & Skala & Pengukuran \\
\hline 1 & $\begin{array}{c}\text { Perputaran } \\
\text { MK }\end{array}$ & $\begin{array}{c}\text { Rasio yang dipakai } \\
\text { untuk melihat } \\
\text { keefektifan modal } \\
\text { kerja pada suatau } \\
\text { perusahaan. }\end{array}$ & Rasio & Perputaran $M K=\frac{\text { Pendapatan }}{\text { Rata }- \text { rata modal kerja }}$ \\
\hline 2 & $\begin{array}{c}\text { Perputaran } \\
\text { Kas }\end{array}$ & $\begin{array}{c}\text { Rasio yang } \\
\text { digunakan untuk } \\
\text { mengukur } \\
\text { seberapa cepat aset } \\
\text { lancar kembali } \\
\text { menjadi kas } \\
\text { melalui penjualan. }\end{array}$ & Rasio & Perputaran Kas $=\frac{\text { Penjualan }}{\text { Rata }- \text { rata kas }}$ \\
\hline 3 & $\begin{array}{c}\text { Perputaran } \\
\text { Persediaan }\end{array}$ & $\begin{array}{c}\text { Untuk mengukur } \\
\text { berapa kali } \\
\text { persediaan dala } \\
\text { perusahaan } \\
\text { berputar. }\end{array}$ & Rasio & P.Persediaan $=\frac{\text { Penjualan }}{\text { Rata }- \text { rata persediaan }}$ \\
\hline
\end{tabular}


Karunia Putri Augustina Dwi Anggiyani, Leni Nur Pratiwi, Banter Laksana

\begin{tabular}{|c|c|c|c|c|}
\hline No & Jenis Variabel & Definisi & Skala & Pengukuran \\
\hline 4 & $\begin{array}{l}\text { Perputaran } \\
\text { Piutang }\end{array}$ & $\begin{array}{c}\text { Rasio untuk } \\
\text { mengukur } \\
\text { seberapa sering } \\
\text { piutang berputar } \\
\text { dalam perusahaan. }\end{array}$ & Rasio & Perputaran piutang $=\frac{\text { Penjualan }}{\text { Rata }- \text { rata piutang }}$ \\
\hline 5 & $\begin{array}{l}\text { Hutang } \\
\text { Jangka } \\
\text { Pendek }\end{array}$ & $\begin{array}{c}\text { Kewajiban yang } \\
\text { harus dilunasi } \\
\text { perusahaan satu } \\
\text { tahn sejak taggal } \\
\text { neraca }\end{array}$ & & $\begin{array}{l}\text { Hutang jangka pendek yang terdapat pada laporan } \\
\text { keuangan triwulan tahun 2017-2019 }\end{array}$ \\
\hline 6 & $\begin{array}{l}\text { Net Profit } \\
\text { Margin } \\
\text { (NPM) }\end{array}$ & $\begin{array}{l}\text { Rasio yang dipakai } \\
\text { untuk melihat } \\
\text { berapa } \\
\text { kemampuan } \\
\text { perusahaan dalam } \\
\text { menghasilkan laba }\end{array}$ & Rasio & $N P M=\frac{\text { Laba bersih setelah pajak }}{\text { penjualan }}$ \\
\hline
\end{tabular}

Sumber : Hasil Olah Data

\section{Teknik Analisis Datai}

Dalam analsis data peneliti melakukan pengujian sebagai berikut :

\section{Analisis Regresi Linear Bergandaa}

Analisis ini digunakan untuk menilai hubugan dan pengaruh antra variabel bebas yang lebih dri satu terhadap variable terikat. Teknik analisis ini digunakan untuk penelitian yang menggunakan beberapa variabel sekaligus. Rumus multiple regresi linear berganda adalah:

$$
Y=a+b 1 \times 1+b 2 \times 2+b 3 \times 3+b 4 x 4+b 5 \times 5+e
$$

Keterangan:

$\mathrm{Y}=\mathrm{NPM}$ merupakan variabel terikat

$\mathrm{x} 1=$ Perputaran Modal Kerja

$\mathrm{x} 2 \mathrm{i}=$ Perputaran Persediaan

$\mathrm{x} 3 \mathrm{i}=$ Perputaran Kas

$\mathrm{x} 4 \mathrm{i}=$ Perputaran Piutang

x5 = Hutang Jangka Pendek

b1-b5 = Koefisien 1

$\mathrm{e}=$ Nilai error

\section{Uji Asumsi Klasik}

Untuk memahami hubungan yang signifikan antar variabel, peneliti menggunakan pengujian asumsi klasik untuk menuji model regresi. Dalam uji asumsi klasik ada empat pengujia yaitu uji multikolinaritas, normalitas, heterokedastisitas dan autokorelasi.

3. Uji Autokorelasi

a. Uji t

Uji t dipakai untk melihat apakh variabel terikat secara individu dipengaruhi oleh 
variabel bebas. Uji t dilakukn dengan cara sebagai berikut :

1) Membandingkan nilai t hitung dengan nilai t tabel. Jika thitung lebih besar dari ttabel, dapat disimpulkan variable terikat dipengaruhi oleh variabel bebas. Begitu juga sebaliknya

2) Membandingkan nilai signifikansi, jka nilai signifikansi $>$ dari 0,05 maka variabel terikat dipengaruhi oleh variabel terikat. Begitu juga sebaliknya.

\section{Uji Koefisien Determinasi $\left(\mathbf{R}^{2}\right)$}

Peneliti melakukan pengujian ini untuk mengukur berapa persen pengaruh dari variable bebas terhadap variable terikat.

\section{Hasil dan Pembahasan}

\section{Uji Normalitas}
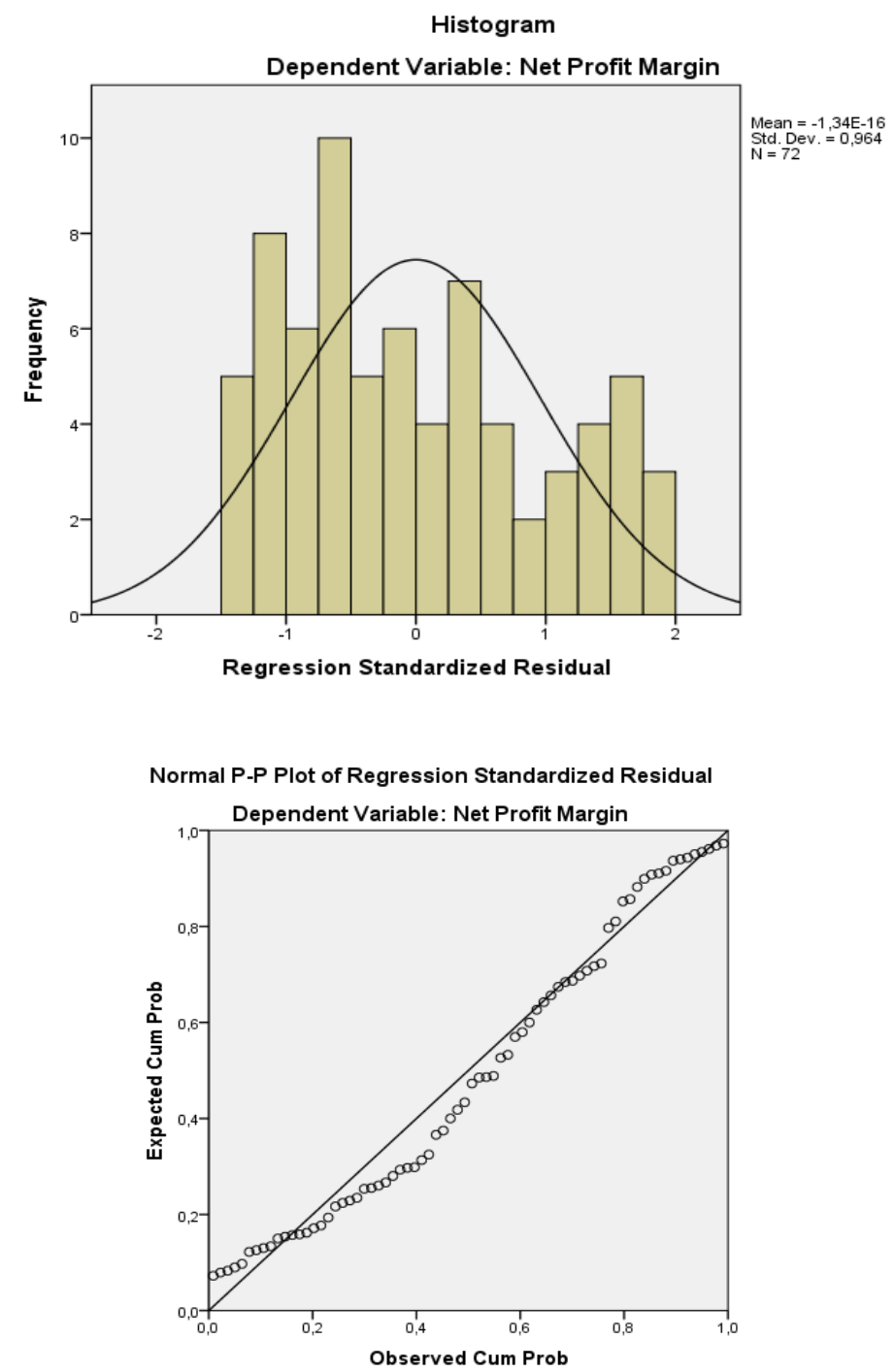

Sumber: Olah Data SPSS

Berdasarkan gambar 1, pada grafik histogram tidak ditemukan penyimpangan yang mencolok dari garis normal, dan kurva P-Plot menunjukan titik-titik tersebar mengikuti garis. Jadi, distribusi 
Karunia Putri Augustina Dwi Anggiyani, Leni Nur Pratiwi, Banter Laksana

data memenuhi persyaratan normalitas.

\section{Uji Multikolinearitas}

Tabel 1. Hasil Uji Multikolinearitas

Coefficients $^{2}$

\begin{tabular}{|c|c|c|c|c|c|c|c|c|}
\hline \multirow[b]{2}{*}{ Mod } & & \multicolumn{2}{|c|}{$\begin{array}{l}\text { Unstandardized } \\
\text { Coefficients }\end{array}$} & \multirow{2}{*}{$\begin{array}{c}\begin{array}{c}\text { Standardiz } \\
\text { ed } \\
\text { Coefficien } \\
\text { ts }\end{array} \\
\text { Beta }\end{array}$} & \multirow[b]{2}{*}{$\mathrm{t}$} & \multirow[b]{2}{*}{ Sig. } & \multicolumn{2}{|c|}{ Collinearity Statistics } \\
\hline & & B & Std. Error & & & & Tolerance & VIF \\
\hline \multirow[t]{6}{*}{1} & (Constant) & 25,047 & 2,391 & & 10,473 &, 000 & & \\
\hline & $\begin{array}{l}\text { Perputaran Modal } \\
\text { Kerja }\end{array}$ & $-1,063$ & 257 &,- 420 & $-4,139$ &, 000 & 670 & 1,492 \\
\hline & Peputaran Persediaan & $-2,991$ &, 567 &,- 634 & $-5,278$ &, 000 & 479 & 2,089 \\
\hline & Perputaran Kas &,- 015 &, 013 &,- 106 & $-1,111$ &, 271 &, 763 & 1,311 \\
\hline & Perputaran Piutang & 1,029 &, 413 &, 321 & 2,493 &, 015 & 417 & 2,399 \\
\hline & Hutang Jangka Pendek & $-4,836 \mathrm{E}-7$ &, 000 &,- 388 & $-4,213$ &, 000 &, 813 & 1,230 \\
\hline
\end{tabular}

a. Dependent Variable: Net Profit Margin

Sumber: Olah Data SPSS

Berdasarkan tabel 1 dapat dilihat hasil pengujian multikolinearitas menunjukan bahwa variable bebas memperoleh tolerance lebih dari 0,1 dan nilai VIF lebih dari 10. Maka data diatas terbebas dari multikolinearitas.

\section{Uji Heteroskedastisitas}

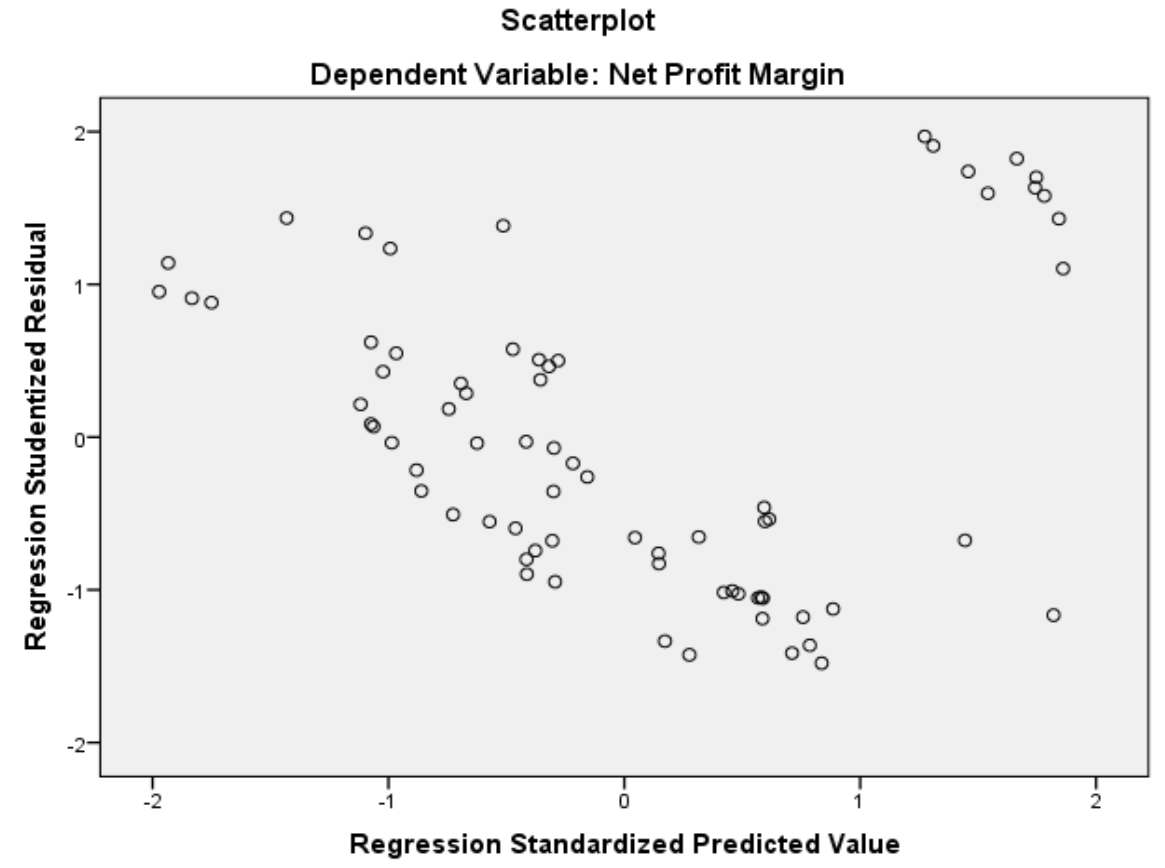

Gambar 2. Hasil Pengujian Heteroskedastisitas 
Sumber: Olah Data SPSS

Gambar 2 diatas memperlihatkan titik-titik yang berada di scatterplot menyebar di sekitaran angka nol dan tidak membentuk pola. Maka dapat disimpulkan pada model persamaan regresi linier berganda tidak terjadi heteroskedastisitas.

\section{UjiiAutokorelasi}

Tabel 2. Hasil Run Test

\begin{tabular}{|l|r|}
\hline \multicolumn{2}{|c|}{ Runs Test } \\
\hline & $\begin{array}{c}\text { Unstandardized } \\
\text { Residual }\end{array}$ \\
\hline Test Value $^{2}$ &,- 91528 \\
Cases < Test Value & 36 \\
Cases >= Test Value & 36 \\
Total Cases & 72 \\
Number of Runs & 38 \\
Z &, 237 \\
Asymp. Sig. (2-tailed) &, 812 \\
\hline
\end{tabular}

a. Median

Sumber : Olah Data SPSS

Dari uji run test diatas diperoleh hasil Asymp.Sig. (2-tailed) sebesar 0,812 > 0,05. Maka dapat disimpulkan tidak terjadi autokorelasi.

\section{Analisis Regresi Linier Berganda}

Tabel 3. Hasil Pengujian Regresi Linier Berganda

\begin{tabular}{|c|c|c|c|c|c|c|}
\hline \multicolumn{7}{|c|}{ Coefficients $^{a}$} \\
\hline & & Unstandardiz & oefficients & $\begin{array}{l}\text { Standardized } \\
\text { Coefficients }\end{array}$ & & \\
\hline \multicolumn{2}{|c|}{ Model } & B & Std. Error & Beta & $\mathrm{t}$ & Sig. \\
\hline \multirow[t]{6}{*}{1} & (Constant) & 25,047 & 2,391 & & 10,473 &, 000 \\
\hline & Perputaran Modal Kerja & $-1,063$ &, 257 &,- 420 & $-4,139$ &, 000 \\
\hline & Perputaran Persediaan & $-2,991$ &, 567 &,- 634 & $-5,278$ &, 000 \\
\hline & Perputaran Kas &,- 015 &, 013 &,- 106 & $-1,111$ & 271 \\
\hline & Perputaran Piutang & 1,029 & 413 & 321 & 2,493 &, 015 \\
\hline & Hutang Jangka Pendek & $-4,836 \mathrm{E}-7$ &, 000 &,- 388 & $-4,213$ &, 000 \\
\hline
\end{tabular}

a. Dependent Variable: Net Profit Margin

Sumber : Olah Data SPSS

Berdasarkan tabel 3 diatas di dapat perasaan regresi linier berganda sebagai berikut : 


$$
\mathrm{NPM}=25,047-1,063-2,991-0,015+1,029-4,836+2,391
$$

1. Konstanta a sebesar 25,047 menunjukan bahwa apabila bebas dalam keadaan tetap maka nilai NPM sebesar 25,047.

2. Koefisien Regresi Perputaran Modal Kerja, Perputaran Persediaan, Perputaran Kas dan Hutang Jangka Pendek memperoleh hasil yang negatif. Jadi dapat disimpulkan ketika variabel tersebut mengalami kenaikan dan variabel lain tetap, maka NPM akan turun.

3. Koefisien Regresi Perputaran Piutang diperoleh sebesar 1,029, artinya ketika perputaran piutang naik sebesar 1\% maka NPM akan turun sebesar 1,029 satuan.

\section{Uji Hipotesis}

a. Uji t

Tabel 4. Hasil Pengujian $\mathrm{t}$

\begin{tabular}{|c|c|c|c|c|c|c|}
\hline \multicolumn{7}{|c|}{ Coefficients ${ }^{2}$} \\
\hline \multirow{2}{*}{\multicolumn{2}{|c|}{ Model }} & \multicolumn{2}{|c|}{ Unstandardized Coefficients } & \multirow{2}{*}{$\begin{array}{c}\begin{array}{c}\text { Standardized } \\
\text { Coefficients }\end{array} \\
\text { Beta }\end{array}$} & \multirow[b]{2}{*}{$\mathrm{t}$} & \multirow[b]{2}{*}{ Sig. } \\
\hline & & B & Std. Error & & & \\
\hline \multirow[t]{6}{*}{1} & (Constant) & 25,047 & 2,391 & & 10,473 &, 000 \\
\hline & Perputaran Modal Kerja & $-1,063$ &, 257 &,- 420 & $-4,139$ &, 000 \\
\hline & Perputaran Persediaan & $-2,991$ &, 567 &,- 634 & $-5,278$ &, 000 \\
\hline & Perputaran Kas &,- 015 &, 013 &,- 106 & $-1,111$ &, 271 \\
\hline & Perputaran Piutang & 1,029 & 413 & 321 & 2,493 &, 015 \\
\hline & Hutang Jangka Pendek & $-4,836 \mathrm{E}-7$ &, 000 &,- 388 & $-4,213$ &, 000 \\
\hline
\end{tabular}

a. Dependent Variable: Net Profit Margin

Sumber: Olah Data SPSS

Berdasarkan tabel 4 diatas maka dapat disimpulkan :

1. Variabel perputaran modal kerja, perputaran persediaan dan hutang jangka pendek memiliki t hitung yang negatif dan lebih kecil dari nilai t tabel yaitu 1,996. Namun memiliki nilai signifikansi sebesar $0,00<0,05$. Maka dapat disimpulkan NPM secara parsial dipengaruhi oleh perputaran modal kerja, perputaran persediaan dan hutang jangka pendek dengan pengaruh yang negatif dan signifikan.

2. Variabel perputaran kas memiliki thitung yang negatif dan lebih kecil dari nilai t tabel yaitu 1,996. Namun nilai signifikansi yang di peroleh sebesar 0,271 >0,05. Maka dapat disimpulkan NPM secara parsial tidak dipengaruhi oleh perputaran kas.

3. Variabel perputaran piutang memiliki t hitung sebesar 2,493 $>1,996$ dan memiliki nilai signifikansi sebesar 0,00 lebih kecil dari 0,05. Maka NPM secara parsial dipengaruhi oleh perputaran piutangdengan pengaruh yang positif dan signifikan.

\section{b. Uji F}

Tabel 5. Hasil Pengujian F 


\begin{tabular}{|cc|r|r|r|r|r|}
\hline \multicolumn{1}{|c|}{ Model } & & Sum of Squares & \multicolumn{1}{c|}{ Df } & Mean Square & F & Sig. \\
\hline 1 & Regression & 4783,801 & 5 & 956,760 & 15,782 &, $000^{\mathrm{b}}$ \\
& Residual & 4001,087 & 66 & 60,623 & & \\
& Total & 8784,888 & 71 & & & \\
\hline
\end{tabular}

a. Dependent Variable: Net Profit Margin

b. Predictors: (Constant), Hutang Jangka Pendek, Perputaran Kas, Perputaran Modal Kerja, Peputaran Persediaan, Perputaran Piutang

Sumber : Olah Data SPSS

Berdasarkan tabel 5 diatas, diperoleh nilai $\mathrm{F}$ hitung sebesar 15,782 lebih besar dari nilai $\mathrm{F}$ tabel sebesar 2,36 dan nilai signifikan yang diperoleh sebesar $0,00<0,05$. Maka dapat disimpulkan bahwa NPM secara simultan dipengaruhi oleh perputaran komponen modal kerja dengan pengaruh yang positif dan signifikan.

Uji Koefisien Determinasi $\left(\mathbf{R}^{2}\right)$

Tabel 6. Hasil Pengujian Koefisien Determinasi

Model Summary ${ }^{b}$

\begin{tabular}{|l|r|r|r|r|r|}
\hline $\begin{array}{l}\text { Mode } \\
1\end{array}$ & $\mathrm{R}$ & $\mathrm{R}$ Square & \multicolumn{1}{c|}{$\begin{array}{c}\text { Adjusted R } \\
\text { Square }\end{array}$} & $\begin{array}{c}\text { Std. Error of } \\
\text { the Estimate }\end{array}$ & Durbin-Watson \\
\hline 1 &, $738^{\mathrm{a}}$ &, 545 &, 510 & 7,78605 & 2,355 \\
\hline
\end{tabular}

a. Predictors: (Constant), Hutang Jangka Pendek, Perputaran Kas, Perputaran Modal Kerja,

Perputaran Persediaan, Perputaran Piutang

b. Dependent Variable: Net Profit Margin

Sumber : Olah Data SPSS

Berdasarkan tabel 6 diatas, diperoleh hasil sebagai berikut :

1. Diperoleh nilai Koefisien Korelasi (R) sebesar 0,738 x 100\% = 73,8\%. Maka dapat disimpulkan hubungan antara variabel bebas terhadap variabel terikat memiliki korelasi yang positif dan mempunyai hubungan yang kuat.

2. Koefisien Determinasi $\left(\mathrm{R}^{2}\right)$ diperoleh sebesar $0,510 \times 100 \%=51 \%$. Maka dapat disimpulkan pengaruh variabel bebas terhadap variabel terikat sebesar $51 \%$ dan sisanya di pengaruh oleh faktor-faktor lain yang tidak di bahas dalam penelitian ini.

\section{Pembahasan}

\section{1) Net Profit Margin (NPM) dipengaruhi oleh variabel perputaran modal kerja}

Dalam menjalankan usahanya kegiatan operasional perusahaan didanai oleh modal kerja yang memiliki sifat yang variatif, berputar secara cepat dan fleksibel. Modal kerja

yang tinggi pada suatu perusahaan menandakan adanya dana menganggur dan perusahaan dinilai tidak produktif, sehingga akan mengakibatkan turunnya profitabilitas perusahaan. Namun, modal kerja yang kecil dapat meningkatkan resiko terganggunya kegiatan operasional perusahaan. Dengan besarnya jumlah investasi yang ditanamkan dalam modal kerja, perusahaan mengharapkan investasi 
ini secara signifikan dapat mempengaruhi profitabilitas perusahaan. Karena itu, perusahaan berusaha mengoptimalkan modal kerja dengan membayar tagihan selambat mungkin, mengembalikan persediaan menjadi kas dengan cepat, dan menagih piutang dengan cepat. (Enqvist, Graham, dan Nikkinen, 2014)

Berdasarkan tabel 5 menunjukkan bahwa NPM dipengaruhi oleh variabel perputaran modal kerja, namun pengaruhnya negative dan signifikan. Hasil tersebut ditunjukan dengan nilai thitung $-4,139<1,996$. Selain itu nilai probabilitas yang diperoleh sebesar $0,00<0,05$. Maka hipotesis satu (H1) yang menyatakan perputaran modal kerja mempunyai pengaruh positif terhadap NPM ditolak. Semakin tinggi tingkat perputaran modal kerja akan diikuti dengan penurunan NPM.

Hasil tersebut sejalan dengan penelitian Prakoso, Zahroh dan Nuzula (2014) yang menyatakan bahwa profitabilitas dipengaruhi oleh variabel perputaran modal kerja dengan pengaruh yang negatif dan signifikan.

\section{2) Net Profit Margin (NPM) dipengaruhi oleh variabel perputaran persediaan}

Unsur modal kerja yang mempunyai peran penting dalam menghasilkan laba adalah persediaan. Persediaan adalah modal kerja operasional yang dapat dioptimalkan dan dipengaruhi oleh kegiatan perusahaan (Garba, Mourab dan Chamo, 2019). Rasio ini dipakai untuk mengukur sebarapa efektif perusahaan dalam mengelola persediaan nya. Cepatnya rasio ini dalam perusahaan menandakan persediaan dalam perusahaan dapat dijual dengan cepat sehingga tidak menimbulkan resiko barang rusak karena terlalu lama di gudang. Hal tersebut dapat meningkatkan penjualan perusahaan sehingga keuntungan perusahaan juga akan meningkat.

Berdasarkan tabel 5 menunjukkan bahwa pada industri makanan minuman, NPM dipengaruhi oleh variabel perputaran persediaan dengan pengaruh yang negatif dan signifikan. Hasil ini ditunjukan dengan diperolehnya nilai thitung yaitu $-5,278<1,996$. Selain itu nilai probabilitas yang diperoleh sebesar $0,00<0,05$. Maka perputaran persediaan berpengaruh negatif signifikan terhadap NPM. Sehingga, ketika perputaran persediaan mengalami penurunan maka NPM dalam perusahaan akan meningkat. Hal tersebut disebabkan karena perusahaan menjual persediaan nya lebih mahal dari tahun sebelumnya, sehingga ketika perputaran persediaan turun artinya persediaan yang dijual perusahaan lebih sedikit dibandingkan tahun sebelumnya, namun NPM dalam perusahaan akan tetap meningkat karena harga jual persediaan lebih mahal. Penelitian ini sesuai dengan hasil penelitian Nurafika dan Almadany (2018) dan Garba, Mourab dan Chamo (2019) yang menyatakan bahwa profitabilitas dipengaruhi oleh perputaran persediaan dengan pengaruh yang negatif.

\section{3) Net Profit Margin (NPM) dipengaruhi oleh variabel perputaran kas}

Rasio perputaran kas digunakan para investor dan kreditor untuk mengetahui seberapa besar penjualan yang dapat dihasilkan dari kas yang dipunya oleh perusahaan.

Kas yang berputar cepat dalam perusahaan menunjukan tingginya volume penjualan dalam perusahaan. Sebaliknya jika perputaran kas dalam perusahaan semakin rendah dan semakin lambat menggambarkan perusahaan tidak efisien dalam menggunakan kas nya.

Berdasarkan tabel 5 menunjukkan bahwa pada industri makanan minuman, perputaran kas tidak memiliki pengaruh terhadap NPM. Hasil ini ditunjukan dengan diperolehnya nilai $\mathrm{t}$ hitung sebesar $-1,111<1,996$. Selain itu nilai probabilitas yang diperoleh sebesar 0,271 > 0,05. Maka disimpulkan bahwa NPM tidak dipengaruhi oleh variabel perputaran kas. Hasil penelitian ini sesuai dengan penelitian oleh Wulandari, Oemar, Hartono (2017) dan Rolos, Murni dan Saerang (2014) yang menyatakan NPM tidak dipengaruhi oleh variabel perputaran kas.

4) Net Profit Margin (NPM) dipengaruhi oleh variabel perputaran piutang 
Piutang merupakan tagihan yang dimiliki perusahaan terhadap pihak lain dalam bentuk uang. Piutang merupakan jumlah yang harus dibayar klien kepada perusahaan yang berkaitan dengan kegiatan operasional (Serrasqueiro, 2014). Untuk mengukur efisiensi piutang dalam perusahaan dapat menggunakan perputaran piutang. Semakin cepat perputarannya maka semakin kecil risiko tidak tertagihnya piutang. Sebaliknya, jika perputaran piutang semakin rendah maka akan memperbesar resiko tidak tertagihnya piutang.

Melalui analisis regresi berganda pada penelitian ini, didapatkan hasil NPM dipengaruhi oleh variabel perputaran piutang dengan pengaruh yang positif dan signifikan. . Hasil ini ditunjukan dengan diperolehnya t hitung $2,493>1,996$. Selain itu nilai probabilitas yang diperoleh sebesar $0,015<0,05$. Maka dapat disimpulkan bahwa NPM dipengaruhi oleh perputaran piutang. Sehingga ketika perputaran piutang mengalami kenaikan maka NPM perusahaan pun akan naik. Begitu juga sebaliknya, jika perputaran piutang turun maka NPM dalam perusahaan juga akan turun. Dan hal tersebut menggambarkan kecilnya risiko tidak tertagihnya piutang pada perusahaan.

Penelitian ini sejalan dengan penelitian Rolos, Murni dan Saerang (2014) yang menyatakan NPM dipengaruhi oleh perputaran piutang dengan pengaruh yang positif. Hal tersebut disebabkan karena piutang yang dimiliki perusahaan tertagih, sehingga piutang tersebut dapat kembali menjadi kas yang digunakan untuk kegiatan operasional perusahaan.

\section{5) Pengaruh Hutang Jangka Pendek terhadap Net Profit Margin (NPM)}

Utang jangka pendek menurut Munawir (2014 : 18) adalah hutang yang harus dilunasi perusahaan satu tahun sejak tanggal neraca. Berdasarkan tabel 5 menunjukkan bahwa pada industri makanan minuman, hutang jangka pendek berpengaruh negatif signifikan terhadap NPM. Variabel hutang jangka pendek memperoleh t hitung sebesar -4,213 lebih kecil dari nilai t tabel yaitu 1,996. Selain itu nilai probabilitas yang diperoleh sebesar 0,000 lebih kecil dari tingkat signifikansi 0,05 . Maka NPM dipengaruhi oleh variabel hutang jangka pendek, namun pengaruhnya negatif. Sehingga kenaikan hutang jangka pendek akan mengakibatkan turunnya NPM perusahaan.

Hasil ini sesuai dengan penelitian Sunaryo (2018) yang menyatakan profitabilitas dipengaruhi oleh hutang jangka pendek dengan pengaruh yang negatif dan signifikan. Hal ini disebabkan karena tingginya hutang jangka pendek yang dimiliki perusahaan

untuk mendanai persediaan didalam gudang, maka beban bunga yang harus dibayar oleh perusahaan juga semakin tinggi. Hal tersebut akan menyebabkan risiko perusahaan tidak dapat memenuhi kewajibannya sehingga akan mengganggu profitabilitas perusahaan.

\section{Penutup}

\section{Kesimpulan}

Berdasarkan penelitian yang telah dilakukan, maka dapat disimpulkan :

1. NPM secara parsial dipengaruhi negatif dan signifikan oleh variabel perputaran modal kerja, perputaran persediaan dan hutang jangka pendek

2. NPM secara parsial tidak dipengaruhi oleh variabel perputaran kas

3. NPM secara parsial dipengaruhi positif dan signifikan oleh variabel perputaran piutang

4. NPM secara simultan dipengaruhi positif dan signifikan oleh variabel perputaran modal kerja, perputaran persediaan, perputaran kas, perputaran piutang dan hutang jangka pendek

\section{Saran}

Berdasarkan penelitian yang telah dilakukan, maka peneliti memberikan masukan sebagai berikut : 
1. Bagi perusahaan

a. Sebaiknya manajemen lebih memperhatikan perputaran masing-masing elemen dari modal kerja dan mengelolanya dengan baik, agar dapat meningkatkan profitabilitas dalam perusahaan.

b. Sebaiknya manajemen lebih meningkatkan penjualan, karena penjualan yang tinggi akan meningkatkan keuntungan perusahaan. Sehingga profitabilitas dalam perusahaan akan meningkat.

2. Bagi Penanam modal

Sebaiknya para penanam modal dapat menjadikan keuntungan perusahaan sebagai patokan dalam mengambil keputusan ketika akan melakukan investasi

3. Bagi Peneliti Selanjutnya

Bagi peneliti selanjutnya, disarankan untuk memakai data terbaru untuk penelitian sehingga mendapatkan hasil yang akurat dan disarankan untuk mengambil sampel tidak hanya pada perusahaan makanan dan minuman saja, tapi dapat mengambil sektor industri lain yang ada di BEI.

\section{Daftar Pustaka}

Anita. (2017). Pengarub perputaran piutang terhadap sisa hasil usaha pada koperasi simpan pinjam karya sultra jaya kendari. Universitas Halu Oleo.

Baridwan, Z. (2014). Intermediate Accounting (Kedelapan). BPFE.

Enqvist, J., Graham, M., dan Nikkinen, J. (2014). The impact of working capital management on firm profitability in different business cycles: Evidence from Finland, Research in International Business and Finance. Research in International Business and Finance, 32, 36-49.

Garba, S., Mourab, B., dan C. (2019). The Effect of Inventory Turnover Period on the Profitability of Listed Nigerian Conglomerate Companies. International Journal of Financial Research, 11(2), 288.

Kementerian Perindustrian. (2018). Industri Makanan dan Minuman Jadi Sektor Kampiun. 30 April 2019. http://www.kemenperin.go.id

Marda. (2019). Pengaruh modal kerja terhadap profitabilitas pada PT. Astra International Tbk di bursa efek indonesia. Universitas Negeri Makasar.

Muslimah, K. N. N., \& Syarief, M. E. (2020). Pengaruh Manajemen Modal Kerja Terhadap Kinerja Keuangan Perusahaan Manufaktur di Indeks Saham Syariah. Journal of Applied Islamic Economics and Finance, 1(1), 54-70.

Munawir. (2014). Analisa Laporan Kenangan (Keempat). Liberty.

Nurafika, Rika Ayu dan Almadany, K. (2018). Pengaruh perputaran kas, perputaran piutang, perputaran persediaan terhadap profitabilitas pada perusahaan semen. Jurnal Akuntansi Dan Bisnis, 4(1).

Prakoso, Bangiun, Z.A, Zahroh dan Nuzula, N. F. (2014). Pengaruh perputaran modal kerja dan perputaran piutang terhadap profitabilitas (studi pada perusahaan pembiayaan listing di BEI periode 2009-2013). Jurnal Administrasi Bisnis, $15(1), 7$.

Putri, P., \& Sudiartha, G. (2015). Pengaruh Modal Kerja Terhadap Profitabilitas Perusahaan Food and Beverages. E-Jurnal Manajemen Universitas Udayana, 4(2), 255279.

Riyanto, B. (2010). Dasar-Dasar Pembelanjaan Perusahaan (Keempat). BPFE. 
Saerang, I., Murni, S., \& Rolos, O. M. (2014). Modal Kerja Pengaruhnya Terhadap Net Profit Margin Pada Perusahaan Tambang Yang Terdaftar Di Bursa Efek Indonesia. Jurnal Riset Ekonomi, Manajemen, Bisnis Dan Akuntansi, 2(2), 890-901.

Serrasqueiro, J. . (2014). Working Capital Management impact on Profitability. International Master of Science in Business Administration.

Setiawan, S., \& Sari, R. M. (2018). Rentabilitas Bank Umum Syariah Sesudah Spin-Off Berdasarkan Tipe Pemisahannya Di Indonesia. Amwaluna: Jurnal Ekonomi dan Kenangan Syariah, 2(1), 69-87.

Sofyan, A. F., \& Saifi, M. (2018). Modal Kerja Dan Profitabilitas Pada Perusahaan Food And Beverages ( Studi pada Perusahaan Sub Sektor Food and Beverages yang Terdaftar Di Bursa Efek Indonesia Periode 2014-2018). 73(1), 169-177.

Sugiyono. (2017). Metode Penelitian Kuantitatif, Kualitatif, dan R\&D. Alfabeta CV.

Sunaryo, D. (2018). Pengaruh utang jangka pendek dan utang jangka panjang terhadap profitabilitas pada perusahaan industri makanan dan minuman yang terdaftar di bursa efek indonesia (BEI) periode tahun 2013-2017. Jurnal Sains Manajemen, 4.

Susanti, Cristina, D., Rahayu, Sri, M. D. T. (2014). Analisis pengelolaan modal kerja dalam usaha menjaga likuiditas dan profitabilitas perusahaan (studi kasus pada PT. Armada pagora jayankediri periode 2011-2013). Jurnal Administrasi Bisnis, 12.

Tarsiah, E. (2017). Pengaruh net profit margin dan likuiditas (current ratio) terhadap harga saham. Bandung. Universitas Komputer Indonesia.

Wulandari, I., Oemar, A., dan H. (2017). Pengarub perputaran modal kerja, perputaran asset tetap, perputaran piutang, perputaran kas, dan perputaran persediaan terbadap Net Profit Margin (NPM) pada perusahaan manufaktur di bursa efek indonesia $p$. Universitas Pandanaran.

Yani, Yosi Andra dan Martha, L. (2019). Pengarub modal kerja terhadap profitabilitas pada perusahaan kosmetik yang terdaftar di bursa efek indonesia. Sekolah Tinggi Ilmu Ekonomi KBP. 